DOI: 10.22630/EIOGZ.2014.107.23

Zeszyty Naukowe Szkoły Głównej Gospodarstwa Wiejskiego

Ekonomika i Organizacja Gospodarki Żywnościowej nr 107, 2014: 35-46

Agnieszka Stanowicka

Katedra Makroekonomii

Uniwersytet Warmińsko-Mazurski w Olsztynie

\title{
Możliwości wykorzystania atrybutów rynku żywności w Polsce w kształtowaniu wizerunku i rozwoju wybranych regionów
}

\section{Wizerunek i jego wpływ na rozwój regionalny}

W dzisiejszych czasach nie budzi wątpliwości fakt, że jakość życia wszystkich podmiotów gospodarujących zależy od wzrostu i rozwoju gospodarczego, które można analizować na poziomie regionu. Rozwój regionalny określany jest jako proces pozytywnych przemian, dotyczących wzrostu produkcji, zatrudnienia, inwestycji, zaangażowanego kapitału, dochodów, spożycia i innych wielkości ekonomicznych, a także społecznych, jak również towarzyszących im zmian o charakterze jakościowym, obejmujących postęp techniczny i technologiczny, optymalizację systemu powiązań wewnętrznych i powiązań z gospodarką światową oraz wzrost poziomu kwalifikacji siły roboczej, a także zmiany struktury gospodarki zmierzające do jej unowocześnienia, wzrost poziomu efektywności w skali mikro- i makroekonomicznej, pojawienie się nowych produktów i doskonalenie jakości tych już produkowanych [Hadyński 2011, s. 9]. Od lat autorzy próbują wskazać na czynniki, które w najistotniejszy sposób determinują rozwój regionu. Okazuje się, że ważnym czynnikiem rozwojowym jest pozytywny wizerunek regionu, który może spowodować przyciągnięcie zasobów kapitału do regionu i pobudzenie w ten sposób jego rozwoju. Coraz częściej mówi się zatem o celowym oddziaływaniu na kształtowanie wizerunku jednostki terytorialnej tak, żeby był on zgodny z pożądanym, a nie przypadkowy. Mówi się wręcz o realizowaniu strategii kształtowania wizerunku, która zostaje wpisana w całokształt strategii rozwoju regionalnego. Takie podejście wymaga zmiany w zachowaniach władz, które powinny przekształcić się z administratorów 
w menedżerów zarządzających potencjałami rozwojowymi występującymi na danym rynku [Słomińska 2007]. Warto w tym miejscu krótko wyjaśnić podstawowe pojęcia, na których opierają się rozważania zawarte w poniższym opracowaniu, tj. pojęcie wizerunku, tożsamości oraz strategii tożsamości.

Wizerunek jest kategorią poznawczą, opisującą całość subiektywnych skojarzeń, wiedzy, opinii, sądów, emocji, jakie mają o danym obiekcie (np. regionie) jego odbiorcy. Wizerunek składa się z elementów poznawczych (wiedza o regionie), emocjonalnych (odczucia i emocje łączone $\mathrm{z}$ regionem) oraz behawioralnym (skłonność do określonego zachowania się względem regionu). Koncepcja ta zakłada więc, że odbiorca posiadając odpowiednią wiedzę na temat regionu oraz łącząc z nim pozytywne emocje jest skłonny wybrać daną ofertę z innych. Często wykreowany, a następnie utrwalony w świadomości nabywcy wizerunek danego terytorium jest przyczyną jego wyboru, zarówno po raz pierwszy, jak i kolejny lub związania się z regionem na dłuższy czas [Florek 2013, s. 85].

Tożsamość zaś jest to zbiór cech charakterystycznych dla regionu, które wyróżniają go spośród innych i wyrażają się wszelkimi działaniami, jakie podejmowane są w regionie, tworząc swoistą jego osobowość i charakter [Łuczak 2000, s. 48]. Tożsamość to suma cech i działań charakterystycznych dla regionu, które odróżniają go od innych [Florek 2013, s. 94]. Tożsamość to też zbiór cech, atrybutów regionu, przez pryzmat których chce być postrzegany przez otoczenie i które tworzą określone tło czy kontekst dla procesu komunikacji z otoczeniem [Czubała, Wiktor 2001]. Są to tzw. wyróżniki tożsamości - atrybuty regionu, które należy eksponować, komunikować otoczeniu tak, aby ukształtowana tożsamość regionu była jak najbardziej wyraźna, czytelna oraz w sposób istotny wyróżniająca region od innych, konkurencyjnych regionów. Dopiero odbiór tożsamości przez otoczenie prowadzi do powstania określonego wizerunku regionu. Plan wskazujący sposoby komunikowania otoczeniu tożsamości regionu z myślą o ukształtowaniu jego pożądanego wizerunku to strategia tożsamości. Strategia ta to zbiór założeń i sposobów, które służą budowaniu, utrwalaniu i redefiniowaniu tożsamości miasta, a w efekcie jej rynkowego odbioru [Altkon 2002, s. 35].

Efektem skutecznej strategii tożsamości ma być pozytywny wizerunek regionu, oparty na wyróżnieniu jego charakterystycznych cech. Atrybuty te, przyciagając uwagę odbiorców, mogą spowodować, że inwestor zaangażuje tu swój kapitał, turysta odwiedzi z zainteresowania ten region, student będzie chciał się tu kształcić, liczba mieszkańców będzie wzrastać (co dalej przyciąga inwestycje), konferencje, targi będą organizowane tu, a nie gdzie indziej - to wszystko może w długim okresie przyczynić się do rozwoju regionu.

Priorytetowym problemem w projektowaniu strategii tożsamości regionu staje się więc poszukiwanie jego cech charakterystycznych. Dokonuje się tego w przeróżnych obszarach. Strategię tożsamości można budować na jakimś jed- 
nym atucie regionu albo na wielu jednocześnie - wyróżniki tożsamości mogą mieć zatem charakter skoncentrowany lub rozproszony [Stanowicka-Traczyk 2008, s. 145]. Autorka spróbuje pokazać, że wyróżników tożsamości można również próbować poszukiwać na rynku żywności. Atrybuty rynku żywności będzie rozumieć jako charakterystyczne cechy rynku żywności, które można wyeksponować w realizowanych strategiach budowania pożądanego wizerunku regionu.

\section{Założenia metodyczne badania}

W poniższym opracowaniu zaprezentowano wyniki badania przeprowadzonego w polskich regionach. Metodą badawczą była ankieta, techniką ankieta pocztowa, a zastosowanym narzędziem badawczym ustrukturyzowany kwestionariusz ankiety. Mimo że podjęto próbę zrealizowania badania na całej badanej populacji, którą stanowi 16 regionów Polski (województw), to jednak błąd braku odpowiedzi wyniósł $62,5 \%$. Wypełnione kwestionariusze ankiety przesłali przedstawiciele sześciu urzędów marszałkowskich. Były to osoby wskazane jako najbardziej kompetentne w urzędach w badanym temacie. W większości ankietę uzupełniono dodatkowo wywiadem pogłębionym, którego celem było uszczegółowienie wybranych, istotnych z punktu widzenia przedmiotu badania, kwestii. Celem badania była ocena możliwości wykorzystania atrybutów rynku żywności regionu w kreowaniu jego wizerunku, co zaprezentowano ostatecznie na przykładzie wspomnianych sześciu regionów, uznając je za przykładowe. Były to województwa podkarpackie, warmińsko-mazurskie, pomorskie, małopolskie, zachodniopomorskie oraz podlaskie. Badanie przeprowadzono w 2013 roku.

\section{Rola atrybutów rynku żywności w budowaniu pożądanego wizerunku regionu}

W pierwszej kolejności pytano respondentów, czy w ogóle w ich regionie realizuje się strategię tożsamości, a więc czy istnieje długookresowy plan kształtowania pożądanego wizerunku regionu. W czterech z badanych regionów wskazano, że zdecydowanie tak. W dwóch jednak, województwach pomorskim i zachodniopomorskim, uznano, że podejmuje się działania nakierowane na kształtowanie wizerunku, ale trudno je nazwać strategią. W większości przypadków działania te mają charakter krótko- lub ewentualnie średniookresowy. Tylko w województwie małopolskim wskazano, że realizowana tam strategia tożsamości ma charakter długookresowy - jest planowana na okres powyżej 8 lat. 
Respondentów zapytano także o miejsce strategii tożsamości w strategii rozwoju regionu. Okazuje się, że strategia tożsamości ma najczęściej charakter pomocniczy w stosunku do innych strategicznych celów sformułowanych w strategii rozwoju. Często też ogranicza się do promocji regionu. Jedynie w województwie warmińsko-mazurskim cel, jakim jest pożądany wizerunek regionu, kierunkuje jego całą strategię rozwoju. Podkreślono też występujące tu sprzężenie zwrotne - strategia rozwoju oddziałuje również na strategię tożsamości, kierunkując jej cel.

Strategia kształtowania wizerunku bazować powinna na tzw. wyróżnikach tożsamości regionu, czyli pewnych atrybutach regionu, które wyróżniają go spośród innych. Skuteczna strategia tożsamości zależy w dużej mierze od oryginalności, niepowtarzalności tych czynników. W zarządzaniu rozwojem regionalnym stale się ich poszukuje. Jednym z obszarów, w którym zdaniem autorki można próbować poszukiwać wyróżników tożsamości regionu, jest rynek żywności. Dlatego w następnej kolejności skupiono się na zasadniczym celu badania, a więc próbowano zorientować się, czy w regionach zauważa się możliwość wykorzystania wyróżników tożsamości związanych z regionalnym rynkiem żywności w budowaniu jego wizerunku i pobudzaniu rozwoju regionu (tab. 1).

\section{Tabela 1}

Rola rynku żywności w rozwoju regionu

\begin{tabular}{|l|l|l|l|l|l|l|}
\hline Odpowiedzi & 1 & 2 & 3 & 4 & 5 & 6 \\
\hline $\begin{array}{l}\text { To, co się dzieje na rynku żywności ma silny } \\
\text { wpływ na to, co się dzieje w regionie }\end{array}$ & & $\mathrm{X}$ & & & $\mathrm{X}$ & \\
\hline $\begin{array}{l}\text { Wybrane elementy rynku żywności rzutuja } \\
\text { na rozwój regionu }\end{array}$ & $\mathrm{X}$ & & & $\mathrm{X}$ & & $\mathrm{X}$ \\
\hline $\begin{array}{l}\text { Nie zauważa się ścisłego związu pomiędzy } \\
\text { rynkiem żywności a rozwojem regionu }\end{array}$ & & & $\mathrm{X}$ & & & \\
\hline $\begin{array}{l}\text { To, co się dzieje na rynku żywności } \\
\text { na pewno nie ma żadnego wpływu } \\
\text { na funkcjonowanie i rozwój regionu }\end{array}$ & & & & & \\
\hline
\end{tabular}

Źródło: Opracowanie własne na podstawie przeprowadzonego badania (1 - województwo małopolskie, 2 - województwo podkarpackie, 3 - województwo podlaskie, 4 - województwo pomorskie, 5 - województwo warmińsko-mazurskie, 6 - województwo zachodniopomorskie)

W pięciu z badanych regionów zauważa się związek rynku żywności z rozwojem regionu, przy czym w dwóch z nich: województwie podkarpackim oraz w województwie warmińsko-mazurskim wskazano na silny wpływ tego, co się dzieje na rynku żywności na rozwój regionu. W dwóch regionach - województwach podlaskim oraz zachodniopomorskim wskazano, że wybrane elementy rynku żywności rzutują na rozwój regionu. Wszystkie regiony uznały, że wybrane elementy rynku żywności mogą stać się ich wyróżnikami. W województwie 
warmińsko-mazurskim wręcz podkreślono, że wszystko, co dzieje się na rynku żywności może stanowić źródło wizerunku regionu. Tylko w jednym regionie nie zauważa się ścisłego związku pomiędzy rynkiem żywności a rozwojem regionu.

Jednym z atrybutów rynku żywności, który potencjalnie mógłby stać się wyróżnikiem regionu, jest jego dziedzictwo kulinarne, będące elementem dziedzictwa kulturowego regionu. Dziedzictwo kulturowe inaczej nazywać można subproduktem kulturowym, rozumiejąc je wtedy jako element złożonego megaproduktu terytorialnego. Należą do niego [Kowalik i Sikora 2007, s. 15]:

1) elementy niematerialne, takie jak kultura, sztuka, język, legendy, architektura, zdobnictwo przedmiotów powszechnego użytku lub zabudowań,

2) elementy materialne, takie jak wyroby rękodzieła regionalnego, stroje, żywność.

Specyfiką dziedzictwa kulturowego jest to, iż jego elementy nie powstawały z myślą, by stać się elementem dziedzictwa kulturowego, lecz dopiero z czasem nabrały takiego znaczenia. Jest to więc stale poszerzający się, heterogeniczny zbiór dóbr wytworzonych w różnych epokach i w różnym celu [Murzyn-Kupisz 2010, s. 64]. Dziedzictwo to powstaje poprzez odkrywanie spuścizny przeszłości i wybór z niej tego, co zostanie uznane za dziedzictwo. Dodatkowo kultura regionu stanowi bardzo istotny element rozwoju regionalnego w Unii Europejskiej [Buzowska 2010, s. 31]. Dlatego temat wydaje się wart zainteresowania oraz rozpoczęcia badań nad możliwością wykorzystania dziedzictwa kulturowego w kreowaniu pożądanego wizerunku regionu. Elementem dziedzictwa kulturalnego na poziomie regionalnym jest regionalne dziedzictwo kulinarne, mogące stać się atrybutem, na bazie którego budowany będzie pożądany wizerunek regionu. Najogólniej przez dziedzictwo kulinarne rozumieć można produkty żywnościowe i potrawy charakteryzujące się szczególnymi cechami jakościowymi, tradycyjnymi sposobami przyrządzania i wytwarzania sięgającymi często odległej historii [Kupracz 2007, s. 102].

W realizowanym badaniu zapytano respondentów o rolę produktów regionalnych z zakresu dziedzictwa kulinarnego regionu w realizowanych strategiach tożsamości. W województwach małopolskim, podkarpackim i warmińsko-mazurskim produkty dziedzictwa kulinarnego są jednym z kluczowych wyróżników tożsamości tych regionów. W pozostałych regionach istnieje wiele produktów regionalnego dziedzictwa kulinarnego, ale nie podjęto prób wykorzystania ich w strategii budowania wizerunku regionu. W żadnym $\mathrm{z}$ badanych regionów nie wskazano, że dziedzictwo kulinarne jest mało wyraziste i nie ma sensu z tego powodu go eksponować.

Dużą rolę w budowaniu tożsamości odgrywa władza miejska odpowiedzialna za wyrażanie kluczowych idei działania. Ona ponosi odpowiedzialność za poli- 
tykę komunikacyjną, formułowanie przekazów skierowanych w stronę otoczenia oraz za całokształt działań związanych z produktami, komunikacją wewnętrzna, zachowaniami na rynku [Łuczak 2001, s. 50]. To ona powinna rozpoznać kluczowe determinanty tożsamości regionu, by umiejętnie je wykorzystać przy komponowaniu instrumentów jej strategii, kształtującej docelowy wizerunek regionu. Wydaje się, że to ambicją władz lokalnych powinno stać się włączenie dziedzictwa kulinarnego do strategii rozwoju regionu, dlatego zbadano problem udziału władz lokalnych w promowaniu dziedzictwa kulinarnego. Wyniki badania w tym zakresie przedstawiono $\mathrm{w}$ tabeli 2 .

\section{Tabela 2}

Rola władz lokalnych w promowaniu dziedzictwa kulinarnego regionu

\begin{tabular}{|l|l|}
\hline Odpowiedzi & \multicolumn{1}{|c|}{ Województwa } \\
\hline $\begin{array}{l}\text { Nie jest rolą władz lokalnych promowanie dziedzictwa kulinarnego } \\
\text { regionu - prywatni przedsiębiorcy, którzy czerpią z tego zyski, } \\
\text { zrobią to lepiej }\end{array}$ & - \\
\hline $\begin{array}{l}\text { Władze lokalne powinny zainspirować właściwe podmioty } \\
\text { i instytucje do działań promujących dziedzictwo kulinarne regionu }\end{array}$ & $\begin{array}{l}\text { małopolskie, } \\
\text { podkarpackie, } \\
\text { zachodniopomorskie }\end{array}$ \\
\hline $\begin{array}{l}\text { Władze regionu powinny włączyć promowanie dziedzictwa } \\
\text { kulinarnego do strategii rozwoju regionu i aktywnie podejmować } \\
\text { działania w tym zakresie }\end{array}$ & $\begin{array}{l}\text { warmińsko- } \\
\text {-mazurskie, } \\
\text { pomorskie }\end{array}$ \\
\hline Brak odpowiedzi & podlaskie \\
\hline
\end{tabular}

Źródło: Opracowanie własne na podstawie przeprowadzonego badania.

Okazuje się, że przedstawiciele regionów warmińsko-mazurskiego i pomorskiego uważają, że władze regionu powinny włączyć promowanie dziedzictwa kulinarnego do strategii rozwoju regionu i podejmować aktywne działania $\mathrm{w}$ tym zakresie. W regionach małopolskim, podkarpackim i zachodniopomorskim uznano, że władze lokalne powinny zainspirować właściwe podmioty i instytucje do działań, promujących dziedzictwo kulinarne regionu. Podmioty, na które wskazywano to restauracje, instytucje kultury, np. muzea, stowarzyszenia, np. koła gospodyń wiejskich, szkoły itp. W żadnym z regionów nie udzielono odpowiedzi, że nie jest rolą władz lokalnych promowanie dziedzictwa kulinarnego regionu, a prywatni przedsiębiorcy, którzy czerpią z tego zyski mogliby zrobić to lepiej.

Kolejną istotną kwestią związaną z funkcjonowaniem rynku żywności są preferencje i zachowania rynkowe konsumentów. Okazuje się, że tak jak na większości rynków, tak i na rynku żywności obserwuje się regionalne zróżnicowanie zachowań tej grupy podmiotów. W każdym regionie zauważa się odmienne gusty, preferencje, przyzwyczajenia, tradycje jeśli chodzi o spożywa- 
nie tych produktów. Są regiony gdzie jada się na przykład więcej wieprzowiny, a w innych więcej wołowiny. Istnieją regiony, gdzie dominuje żywność regionalna, w innych natomiast dziedzictwo kulinarne regionu ma mniejsze znaczenie i zaczyna się konsumować to, co jada się w innych regionach Europy czy nawet świata. Inne są także style konsumpcji - w jednych regionach dominuje kultura regionalna, w innych obserwuje się wpływ globalizacji i ujednolicania się potrzeb konsumentów. W jednych regionach rozwija się sieć restauracji, czasem bardzo ekskluzywnych i modne jest korzystanie $\mathrm{z}$ ich usług, w innych regionach nadal panuje kultura ,jedzenia w domu”. W poszczególnych regionach różne są też determinanty popytu na produkty żywnościowe. Wiadomo, że są regiony biedniejsze, tam zatem głównym kryterium wyborów konsumenta staje się cena. W bogatszych regionach okazuje się, że na plan pierwszy wysuwają się takie kryteria wyboru jak wspominana kultura i tradycje, moda czy jakość.

W województwach podkarpackim i pomorskim zauważa się odmienności w zachowaniach podmiotów rynku żywności. Z kolei w województwach małopolskim i warmińsko-mazurskim widoczne jest ujednolicanie się potrzeb konsumentów żywności. Respondenci są zdania, że są one coraz bardziej zbieżne z globalnymi trendami. Należy jednak zaznaczyć, że są to subiektywne opinie przedstawicieli władz regionu, nie oparte na żadnych badaniach rynku. Dokładne zbadanie regionalnego zróżnicowania zachowań rynkowych konsumentów na rynku żywności przyniosłoby wnioski, które według autorki mogłyby wyłonić wyróżniki regionów, a przez to stać się podstawą realizowanych strategii kształtowania ich wizerunku, przyczyniając się tym samym do ich rozwoju. W przeprowadzonym badaniu pytano respondentów o to, czy bada się zachowania rynkowe konsumentów żywności w regionie. W większości regionów takie badania są prowadzone, ale nie dla potrzeb władz regionu. Robią to inne instytucje (np. naukowe) czy przedsiębiorstwa funkcjonujące na rynku żywności. Jednak badania te prowadzone są na potrzeby własne owych podmiotów - tak jest np. w województwach podlaskim i zachodniopomorskim. Zdaniem autorki, warto by pomyśleć nad przeanalizowaniem wyników tych badań pod kątem możliwości wykorzystania ich w poszukiwaniu wyróżników tożsamości regionu. W województwach małopolskim oraz warmińsko-mazurskim przedstawiciele władz regionu deklaruja, że sporadycznie takie badania są prowadzone, a w województwach podkarpackim i pomorskim na tym poziomie w ogóle nie prowadzi się tego typu analiz. Prawie we wszystkich badanych regionach uznano, że odmienne regionalne tradycje w konsumpcji żywności mogą stać się wyróżnikiem kultury regionu. $\mathrm{Z}$ badanych regionów tylko przedstawiciele województwa pomorskiego nie mają przekonania co do istotności tego zagadnienia. Żaden z respondentów nie zaznaczył natomiast odpowiedzi, że regionalne tradycje związane z rynkiem żywności nie mogą stać się jego atrybutem, bo to za mało 
wyrazisty wyróżnik regionu. Dodać należy jeszcze jeden bardzo ważny wniosek z przeprowadzonego badania - wszyscy respondenci jednomyślnie wskazali, że najważniejszą postacią na rynku żywności jest konsument $\mathrm{i}$ to na nim powinna skoncentrować się uwaga władz, jeśli by w jakikolwiek sposób chciały na rynek żywności oddziaływać, badać lub wykorzystywać jego atrybuty.

Drugą ważną grupą podmiotów rynkowych obok konsumentów są producenci. Analizując dalej problem możliwości wykorzystania atrybutów rynku żywności w kształtowaniu wizerunku regionu, autorka skupiła się również na produkcji żywności w regionie. Okazuje się, że w każdym regionie występuje pewien rodzaj produkcji dominującej i czasem stanowi ona nawet większość produkcji krajowej danego produktu żywnościowego. Dlatego taka dominująca produkcja w regionie również może stać się jego wyróżnikiem, zwłaszcza gdy ma ona zasięg krajowy lub nawet międzynarodowy. Wtedy produkty, które wytworzono w danym regionie, właśnie z nim się kojarzą. Producenci takich produktów zauważają to i wykorzystują nazwę regionu (czy miasta) w budowaniu marki produktu, np. produkty marki Warmia, majonez kętrzyński, pasztet podlaski, napoje Tymbark i wiele innych. Jednak czy władze regionu widzą możliwość wykorzystania produkcji regionalnej na przykład w promocji regionu (tab. 3).

\section{Tabela 3}

Czy produkcja żywności dominująca w regionie może stać się wyróżnikiem w strategii tożsamości regionu?

\begin{tabular}{|l|c|}
\hline Odpowiedzi & Województwo \\
\hline Zdecydowanie tak & $\begin{array}{c}\text { podkarpackie, warmińsko-mazurskie, } \\
\text { zachodniopomorskie }\end{array}$ \\
\hline Trudno powiedzieć & małopolskie, pomorskie \\
\hline Raczej nie, jest to zbyt mało wyraziste & - \\
\hline Brak odpowiedzi & podlaskie \\
\hline
\end{tabular}

Źródło: Opracowanie własne na podstawie przeprowadzonego badania.

W województwach małopolskim i pomorskim nie ma pełnego przekonania $\mathrm{w}$ tej kwestii. Jednak w żadnym z badanych regionów nie zaznaczono odpowiedzi, że zdecydowanie produkcja dominująca $\mathrm{w}$ regionie nie mogłaby stać się wyróżnikiem strategii jego tożsamości.

Na postrzeganie regionu na pewno wpływ mają też wizerunki marek produktów i przedsiębiorstw tam funkcjonujących (mogą to być też produkty spożywcze). Wyróżnić można regiony, które budują swój wizerunek na bazie wizerunku konkretnych przedsiębiorstw, np. Zakłady Mięsne Sokołów, Zakład Mleczarski Warmia itp. Dalsze badania wykazały, że władze wszystkich badanych regionów zdecydowanie zauważają możliwość wyróżnienia dominującej produkcji w regionie, ale w żadnym $\mathrm{z}$ nich nie podjęto w tym kierunku jeszcze działań. Jest to 
więc pewna luka, nad wypełnieniem której można zastanowić się przy poszukiwaniu atrybutów regionu.

Być może jest to szansa na zwrócenie uwagi na dany region i pokazanie, że jest coś, czym wyróżnia się on spośród innych. W strategiach kształtowania wizerunku chodzi wszakże o prezentowanie swojej odmienności w stosunku do innych regionów.

W następnej kolejności zapytano respondentów, czy władze regionu wspierają w jakikolwiek sposób rynek żywności w regionie (tab. 4).

Tabela 4

Czy władze regionu wspierają rynek żywności w regionie?

\begin{tabular}{|l|l|}
\hline Odpowiedzi & Województwo \\
\hline Tak, wspierają producentów żywności & $\begin{array}{l}\text { podkarpackie, pomorskie, } \\
\text { warmińsko-mazurskie, zachodniopomorskie }\end{array}$ \\
\hline $\begin{array}{l}\text { Tak, próbują oddziaływać na kierunki } \\
\text { konsumpcji }\end{array}$ & małopolskie, pomorskie, zachodniopomorskie \\
\hline Tak, promują regionalne tradycje kulinarne & $\begin{array}{l}\text { małopolskie, podkarpackie, podlaskie, } \\
\text { pomorskie, warmińsko-mazurskie, } \\
\text { zachodniopomorskie }\end{array}$ \\
\hline Tak, inne sposoby... & \multicolumn{1}{|c|}{-} \\
\hline Nie & - \\
\hline
\end{tabular}

Źródło: Opracowanie własne na podstawie przeprowadzonego badania.

Wartym zaznaczenia jest fakt, iż $\mathrm{w}$ żadnym $\mathrm{z}$ badanych regionów nie zaznaczono odpowiedzi, że władze regionu w ogóle nie oddziałują na rynek żywności. W województwach podkarpackim, pomorskim, warmińsko-mazurskim oraz zachodniopomorskim władze regionu deklarują, że wspierają regionalnych producentów żywności. Na przykład w województwie małopolskim podkreśla się lobbowanie za zakazem GMO w żywności, gdyż region ten to koncentracja producentów rolnych, których konkurencja modyfikowanych płodów mogłaby zniszczyć.

W województwie podkarpackim wsparcie dla producentów żywności odbywa się poprzez Targi Żywności Ekologicznej „Ekogala”, Festiwal Podkarpackich Smaków, Konkurs „Nasze Kulinarne Dziedzictwo”, Targi Rzemiosła i Przedsiębiorczości „Agrobieszczady”, wsparcie w promocji i dystrybucji produktów. Podobnie w innych regionach organizuje się różne rodzaju targi krajowe i zagraniczne (województwa pomorskie, warmińsko-mazurskie). W województwie warmińsko-mazurskim organizuje się cykl imprez regionalnych poświęconych żywności naturalnej, tradycyjnej, lokalnej, regionalnej (12 imprez tego typu w roku - przykładem może być budzący zainteresowanie Festiwal Dziedzictwa Browarniczego). Władze regionu warmińsko-mazurskiego angażują się również 
w promocję produktów żywności wysokiej jakości. W województwach małopolskim, pomorskim oraz zachodniopomorskim władze regionu próbują też oddziaływać na kierunki konsumpcji. Służą temu wspominane imprezy kulinarne oraz udział w promocji wybranych produktów. W województwie pomorskim władze regionu angażują się $\mathrm{w}$ promocję zdrowego stylu konsumpcji, co jest globalnie modne, ale na poziomie regionalnym trafia bardziej bezpośrednio do konkretnego odbiorcy. Wszystkie badane regiony promują regionalne tradycje kulinarne. Przykładowo w województwie pomorskim są to Pomorskie Święto Produktu Tradycyjnego, Pomorskie Smaki, Muzeum Miodu - podobne wydarzenia i przedsięwzięcia organizowane są we wszystkich badanych regionach.

\section{Wnioski}

Celem artykułu była ocena możliwości wykorzystania atrybutów rynku żywności regionu w kreowaniu jego wizerunku, który w długim okresie może stać się czynnikiem rozwojowym regionu. Zauważono kilka elementów rynku żywności, które potencjalnie mogłyby stać się wyróżnikiem tożsamości regionu. Możliwości te ocenili przedstawiciele władz badanych regionów.

1. W większości badanych regionów wskazano, że wybrane elementy rynku żywności rzutują na rozwój regionu. Były też opinie, że to, co się dzieje na rynku żywności ma silny wpływ na to, co się dzieje w regionie. Tylko w jednym z sześciu badanych regionów nie zauważa się ścisłego związku pomiędzy rynkiem żywności a rozwojem regionu. Pozwala to sądzić, że rzeczywiście problem jest warty zainteresowania i można próbować poszukiwać w rynku żywności charakterystycznych cech dla regionu i w ten sposób wyróżnić go spośród innych.

2. Jednym z wyróżników regionu, związanym z rynkiem żywności, jest dziedzictwo kulinarne regionu. W większości badanych regionów istnieje wiele produktów regionalnego dziedzictwa kulinarnego, ale nie podjęto dotychczas prób wykorzystania ich $\mathrm{w}$ strategii budowania wizerunku regionu. W dwóch z sześciu badanych regionów produkty dziedzictwa kulinarnego są jednym z kluczowych wyróżników tożsamości tych regionów. W żadnym $\mathrm{z}$ badanych regionów nie wskazano, że dziedzictwo kulinarne jest mało wyraziste i nie ma sensu z tego powodu go eksponować, co jest odpowiedzią na pytanie, czy dziedzictwo kulinarne regionu może stać się wyróżnikiem jego tożsamości.

3. Analizując ocenę przedstawicieli władz na temat roli władz lokalnych w promowaniu dziedzictwa kulinarnego regionu, większość badanych stwierdziła, że władze lokalne powinny zainspirować właściwe podmioty i instytucje do 
działań promujących dziedzictwo kulinarne regionu. Władze regionu moga też włączyć promowanie dziedzictwa kulinarnego do strategii rozwoju regionu i aktywnie podejmować działania w tym zakresie.

4. Najważniejszym elementem każdego rynku, w tym także rynku żywności, jest konsument. To, co ważne dla strategii tożsamości to fakt, że zauważa się odmienności w zachowaniach konsumentów żywności w różnych regionach. To regionalne zróżnicowanie gustów, preferencji, upodobań, stylów konsumpcji może również stać się wyróżnikiem regionu i na bazie tego można próbować kształtować pożądany wizerunek regionu. Niestety nie prowadzi się raczej takich badań dla potrzeb wykorzystania ich wyników w strategii kształtowania wizerunku regionu.

5. Kolejny ważny atrybut rynku żywności, który mógłby stać się wyróżnikiem tożsamości regionu, to produkcja dominująca w regionie. Każdy z regionów Polski specjalizuje się w produkcji konkretnych produktów żywnościowych, czasem produkcja niektórych artykułów żywnościowych wręcz koncentruje się w wybranych regionach - można próbować to wyeksponować. Mówiąc o produkcji, warto wspomnieć o tym, że władze regionów już zauważyły możliwości wykorzystania określonych produktów z regionu, które go wyróżniają spośród innych (działanie jest obustronne - producenci żywności często wykorzystują do promocji swoich produktów nazwę regionu, z którego produkty te pochodza).

6. Zauważono też, iż władze regionu próbują oddziaływać na to, co się dzieje na regionalnym rynku żywności. Robią to poprzez wspieranie producentów żywności (np. wysokiej jakości, zdrowej, regionalnej), próbują oddziaływać na kierunki konsumpcji oraz promują regionalne dziedzictwo kulinarne.

\section{Literatura}

ALTKORN J., 2002: Kształtowanie rynkowego wizerunku firmy, Wydawnictwo Akademii Ekonomicznej w Krakowie, Kraków.

BUZOWSKA B., 2010: Marketingowa orientacja w praktyce jednostki samorzqdu terytorialnego - dziedzictwo kulturowe wartościq marketingowa wizerunku powiatu tarnowskiego, Samorząd Terytorialny, nr 3, s. 31.

CZUBAŁA A., WIKTOR J. (red.), 2001: Marketing u progu XXI wieku. Księga jubileuszowa dla uczczenia 70. urodzin prof. J. Altkorna, Akademia Ekonomiczna w Krakowie, Kraków.

FLOREK M., 2013: Podstawy marketingu terytorialnego, Wydawnictwo UE w Poznaniu, Poznań.

HADYŃSKI J., 2011: Strategie rozwoju lokalnego, Wydawnictwo Naukowe UAM, Poznań. 
KOWALIK I., SIKORA T., 2007: Marketing produktów regionalnych, Marketing i Rynek, nr 9, s. 15.

KURPACZ M., 2007: Z problematyki żywności tradycyjnej, Studia Regionalne i Lokalne, nr 4(30), s. 102.

MURZYN-KUPISZ M., 2010: Podmioty na rynku dziedzictwa kulturowego, Studia Regionalne i Lokalne, nr 3(41), s. 64.

ŁUCZAK A., 2000: Istota tożsamości miasta, Samorząd Terytorialny, nr 10, s. 48.

ŁUCZAK A., 2001: Wizerunek miasta, Samorząd Terytorialny, nr 1-2, s. 50.

SŁOMIŃSKA B., 2007: Gmina w procesach stymulowania przedsiębiorczości, Samorząd Terytorialny, nr 3, s. 15.

STANOWICKA-TRACZYK A., 2008: Kształtowanie wizerunku miasta na przykładzie miast polskich, Wydawnictwo Branta, Bydgoszcz.

\title{
The possibilities of using the food market attributes in creating the image and development of the region, based on selected regions of Poland
}

\begin{abstract}
Skilful creation of a region's positive image as a non-material resource may contribute to the region development in long perspective. During this process it is very important to show the attributes of region identity. The author made an attempt to demonstrate the possibilities for the use of food market attributes in creation of region's image. A survey was carried out in six typical regions (NUTS 2) in Poland and the results are presented in the paper. The main important food market attributes are: regional culinary heritage, regional products, prevalent production in region and regional diversity of food consumers behaviour.
\end{abstract}

